\title{
INDUSTRY 4.0 - AS A TECHNOLOGY ENABLER FOR CSR
}

\author{
Mahesh Shinde $^{1}$, Dr. Naim Shaikh ${ }^{2 *}$, Dr. Kishori Kasat ${ }^{3}$
}

\author{
${ }^{1}$ Research Scholar Symbiosis International (Deemed) University Pune 412115 Maharashtra, India \\ ${ }^{2}$ Associate ProfessorGlobal Business School and Research Centre, Dr. D.Y. Patil Vidyapeeth (Deemed to be \\ University)Pune 411033Maharashtra, Indian \\ ${ }^{3}$ Assistant ProfessorSymbiosis Institute of Computer Studies and ResearchSymbiosis International (Deemed) \\ University Pune 411016 \\ 1aim.shaikh@dpu.edu.in, ${ }^{2}$ kishori.kasat@sicsr.ac.in
}

Article History: Received: 11 January 2021; Accepted: 27 February 2021; Published online: 5 April 2021

Abstract:Corporate social responsibility now has become a global phenomenon where businesses all over the world are trying to create and well accepted image in the eyes of stakeholders as well as gain competitive advantage out of such initiatives. The newly evolving themes around corporate social responsibility are not restricted to the social consequences of business action but are built around the aspects like sustainability, resource conservation, waste management, customer satisfaction, power saving and employee satisfaction. These new areas of CSR encompass almost all activities of business and all the systems within the business management. There is ample amount of the research showing correlation between management practices and CSR. The fourth Industrial Revolution is one of the technology-based solutions that is been globally adopted by almost all businesses. This involves cyber physical system-based integration of technology and human effort.This research paper's purposes is to analyse the influence of Industry 4.0 practices independently as well as along with general management practices of the business on CSR. as per the review of literature, the authors have attempted to understand CSR from the evolving perspective of the concept taking it forward from mere business consciousness to socially responsible business practices. The paper analyses how Industry 4.0 based technologies play an effect on cross functional business activities creating a positive impact on CSR initiatives. This study's findings suggest that Industry 4.0 has a positive along with cross functional business activities effect on the CSR practices of organizations. Although individually both Industry 4.0 and cross functional business activities have a positive impact on CSR but combined impact of both Industry 4.0 and cross functional business activities is slightly better. Looked from this perspective Industry 4.0 can serve as a technology enabler for CSR.The research has created a guideline for improving CSR activities of organisations. It is also revealed how human technology interaction-based Industry 4.0 solutions impact the CSR performances of the organisations. The paper proposes a novel approach of integrating Industry 4.0 technology solutions with business activities for solving CSR issues. It is bringing forth impact of Industry 4.0 as a technology enabler on CSR, which never been thought earlier and it contributes the addition in literature available.

Keywords - Industry 4.0, Corporate Social Responsibility, Sustainability, Internet of things, Sustainable development.

\section{Introduction}

Corporate social responsibility has been gaining importance particularly after the second world war wherein the businesses are striving to improve the consequences of business activities on stakeholder groups, community, and Society (Carroll \& Shabana, 2010). Transformation in thinking of businesses based on model of CSR has been hugely contributed to Howard Bowen's book Social Duties of the Businessman was published in 1953.

The growing demand on the business to produce economically, in an environment friendly manner and in a sustainable way has forced industries to look upon the CSR as a competitive advantage provider in business. There is a significant amount of literature pointing out to negative impact of business activities on the environment, Campbell (2007).

Goals of Sustainable Development and the concept of Green Economy are the two major driving forces for CSR activities. Sustainable development goals mainly focusing on Carbon emissions and social sustainability have been propounded by the United States Nations conference on sustainable development 2012. (Towards a green economy: Pathways to sustainable development and poverty eradication, 2011)

The combined pressure of differentiating business on sustainability model and increase consumer awareness has resulted in an increased interest generated by businesses, researchers and academics in the field of CSR. (DeNisi, Wilson \&Biteman, 2014) In spite of this impetus on CSR, there is lack of agreement on definition of CSR. CSR definition changes from region to region, time to time and place to place depending upon the circumstances, nationalities and legal systems operating as well as the consumer awareness and conscience of the industry. (Koo \& Lee, 2015)

In fact there are been as vast as 37 different definitions of CSR. However, there is a consensus about environmental social and economic dimensions of CSR. (Dahlsrud, 2008) One of the most cited and agreed definition of CSR is presented by Archie Carrol, "the social responsibility of business encompasses the 
economic, legal, ethical and discretionary expectations that society has of organizations at a given point in time"'(Carroll, 1979)

Although there is a lack of unanimity on corporate vision regarding CSR, organisations globally are now recognising benefits in terms of acceptability, credibility, environmental performance and competitive advantage in aligning business activities with sustainability through CSR.(Laari, Töyli, Solakivi\&Ojala, 2016) In this ambiguous situation Industry 4.0 provides and synergistic solution amalgamating digital technology with environment friendly consumer demand providing high quality energy efficient customised products.(National Academy of Science and Engineering: Munich, Germany, 2013, Recommendations for Implementing the Strategic Initiative Industry 4.0)

The fourth industrial revolution is taking place now. Industry 4.0, which is driven by cyber physical networks, the industrial IOTs, big data analytics, and other technologies, has a major effect on environmental sustainability. (Bonilla, Set al., 2018). Transitioning to Industry 4.0 poses its own set of challenges. Integration of cyber-physical structures, adoption of emerging digital technology, and changes in the economic landscape work patterns, data security, availability of skilled workforce and establishing appropriate legal framework pose challenges in addition to huge financial investment required. The digital based solutions will require more power and finance. (Wang, Wan, Li \& Zhang, 2016) There exist ambiguity about ability of Industry 4.0 to cope up with these challenges and provide relevant sustainable returns on financial investment and associated social and economic consequences.(Industry 4.0; Study for the European Parliament's Industry, Research and Energy (ITRE) Committee; European Parliament: Brussels, Belgium, 2016.)

The paper purposes to provide an overview on how Industry 4.0 affects various business activities and how their modification consequently impacts CSR. This research will help various stakeholders in the industry for successful adoption of Industry 4.0 technologies.

The paper is structured in the following manner: it describes in a brief the concept of Industry 4.0 technologies. Then based on literature review impact Industry 4.0 technologies on CSR is presented.

As a result, the effects of Industry 4.0 on company practises and processes are investigated, as well as the positive and negative impacts on CSR. Then, possible prospects for integrating Industry 4.0 with the UN SDGs are established, and an outline of the other scenario is explored about CSR initiatives. The topic is primarily focused on a literature review and interaction analysis based on statistical analysis of the experiences of key market stakeholders. Finally, the main observations are presented.

\section{Review of literature}

Industry 4.0 is a German government initiative to re-establish the German pre-eminence in production technology. This enables creation of smart factory manufacturing system based on information and communication technology revolution with the use of technologies like IOT and big data analytics allowing vertical and horizontal integration of business processes(Müller, Buliga\& Voigt, 2018).

Industry 4.0 fundamentally is based on cyber physical systems and IOT as main technologies. Cloud computing, 3D printing, blockchain, bulk data analysis and RFID are all examples of are other offshoot technologies which ad in adoption and implementation of Industry 4.0. (Lu, 2017). Integration of manufacturing and other business processes with Industry 4.0 technologies allows decentralized decision making, automation, virtual realization, simulation, real time data communication and decision making and decentralization improving efficiencies across the value chain(Kiel, Müller, Arnold \& Voigt, 2017).

The benefits of industry 4.0 at production level include increased data analysis and data flow, decentralized automized decision making, increase in overall efficiency, simulation and prediction, creation of a learning environment, vertical and horizontal integration of business processes and overall efficiency is in operation. (Deloitte: London, UK, 2015).

Industry 4.0 allows benefits to the final customer in the way of agile manufacturing, personalized customisation, life cycle analysis including tracking of material and processes, reduced inventory and lead times, novel business models and overall value creation(Stock, T. et al., 2018). However, injudicious use of disruptive technologies can have a negative impact on CSR(Scavarda\&GoyannesGusmãoCaiado, 2019).

CSR should identify Industry 4.0 as holistic driver (Osburg, n.d.). Incorporation of Industry 4.0 in CSR models increases social problem-solving capacity(Potočan, Mulej\&Nedelko, 2020). 
At the same time the value chain performances are improved by adoption of Industry 4.0 technologies through end-to-end digital integration, simulation, and increased physical flexibility of operations (Wan, 2011)

\section{Research Question:}

1) How the Industry 4.0 Technology and Cross Functional Business Activities affects organization's Corporate Social Responsibility?

\section{Objectives:}

1) To do the comparative study of the direct effect of use of Industry 4.0 Technology on Organization's CSR and the combined effect of use of Industry 4.0 Technology and Cross Functional Business Activities of organization.

2) To compare the direct effect of use of Cross Functional Business Activities on organization's CSR and the combined effect of use of Industry 4.0 Technology and Cross Functional Business Activities of organization.

3) To study the combined effect of use of Industry 4.0 Technology and Cross Functional Business Activities on organization's CSR.

\section{Hypothesis:}

$\mathrm{H}_{0}$ : There is a statistically insignificant relationship between CSR and Industry 4.0 Technology and Cross Functional Business Activities.

$\mathrm{H}_{1}$ : There is a statistically significant relationship between CSR and Industry 4.0 Technology and Cross Functional Business Activities.

\section{Research Design}

\section{A] Sample Design:}

$>$ Population: 650

$>$ Sample Design:238 (Ref. Krejcie\& Morgan, 1070) with 95\% Confidence Interval

$>$ Sample Element: Employee from Manufacturing Industry

$>$ Sampling Technique: Simple Random Sampling

B] Research Methodology: In this analysis, the Multiple Regression Method is used to estimate the effect of explanatory variables on the answer variable.

Explanatory Variable-1: Industry 4.0 based technologies

Explanatory Variable-2: Cross functional business activities

Response Variable: CSR practices of organizations

CSR practices of organizations $=$

(Industry 4.0 based technologies) $*$ (Cross functional business activities)

\section{C] Data Collection:}

A Survey questionnaire is prepared to collect the data from respondents. Questionnaire comprised of three sections.Demographic Profile and Five Point Likert Scale is used to know the agreement levels of respondents on constructs Industry 4.0 Technology, Cross functional Business Activities and CSR 3. This section is of subjective question to collect the challenges in CSR and its relevance with Industry 4.0.

Questionnaire was developed with the help of expert's suggestions and content validity performed. Once ensured the reliability and face validity, questionnaire was sent through email to employees of various industries. It was sent to 300 respondents out of which 238 responses received.

D] Data Analysis:

Table-1 COEFFICIENTS

\begin{tabular}{|c|c|c|c|c|c|c|c|c|}
\hline \multirow{2}{*}{$\begin{array}{l}\text { r. } \\
\text { r. } \\
\text { No. }\end{array}$} & \multirow{2}{*}{$\begin{array}{l}\quad \text { Predicto } \\
\mathbf{r} \\
\text { Variable(s) }\end{array}$} & \multirow[t]{2}{*}{$\begin{array}{l}\text { Depende } \\
\text { nt Variable }\end{array}$} & \multirow[t]{2}{*}{ Model } & \multicolumn{2}{|c|}{$\begin{array}{l}\text { Unstandardize } \\
\text { d Coefficients }\end{array}$} & \multirow[t]{2}{*}{$\begin{array}{l}\text { Standardize } \\
\text { d Coefficients }\end{array}$} & \multirow[t]{2}{*}{$t$} & \multirow[t]{2}{*}{ g. } \\
\hline & & & & B & $\begin{array}{c}\text { Std. } \\
\text { Error }\end{array}$ & & & \\
\hline${ }^{1}$ & I4.0T & CSRP & t) (Constan & $\begin{array}{c}- \\
7.006\end{array}$ & $\begin{array}{ll} & 1.78 \\
0 & \end{array}$ & & $\begin{array}{c}- \\
3.936\end{array}$ & $003^{0 .}$ \\
\hline & & & I4.0T & 0.07 & 0.01 & 0.856 & & 0 . \\
\hline
\end{tabular}




\begin{tabular}{|c|c|c|c|c|c|c|c|c|}
\hline & & & & 4 & 4 & & 5.226 & 000 \\
\hline \multirow[t]{2}{*}{$\begin{array}{r}2 \\
\end{array}$} & CFBA & CSRP & t) (Constan & $\begin{array}{ll} & 0.09 \\
8 & \\
\end{array}$ & $\begin{array}{lr} & 0.48 \\
4 & \\
\end{array}$ & & 0.202 & $844^{0}$ \\
\hline & & & CFBA & $\begin{array}{ll} & 0.19 \\
2 & \end{array}$ & $\begin{array}{ll} & 0.04 \\
1 & \end{array}$ & 0.829 & 4.680 & $001^{0}$ \\
\hline \multirow[t]{3}{*}{ ) 3} & \multirow[t]{3}{*}{$\begin{array}{c}\mathrm{I} 4.0 \mathrm{~T} \\
\text { and CFBA }\end{array}$} & \multirow[t]{3}{*}{ CSRP } & t) (Constan & $\begin{array}{c}- \\
5.249\end{array}$ & $6^{1.11}$ & & $\begin{array}{c}- \\
4.501\end{array}$ & $001^{0}$ \\
\hline & & & $\mathrm{I} 4.0 \mathrm{~T}$ & $\begin{array}{ll} & 0.04 \\
9 & \end{array}$ & $\begin{array}{ll} & 0.01 \\
0 & \\
\end{array}$ & 0.570 & 4.717 & $001^{0}$ \\
\hline & & & CFBA & $8^{0.11}$ & 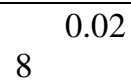 & 0.509 & 4.209 & $002^{0}$ \\
\hline
\end{tabular}

Table-2 MODEL SUMMARY

\begin{tabular}{|c|c|c|c|c|c|c|c|c|}
\hline $\begin{array}{l}\quad \text { S } \\
\text { r. } \\
\text { No. }\end{array}$ & Effect & $\begin{array}{l}\text { Predicto } \\
\text { r Variable }\end{array}$ & $\begin{array}{c}\text { Depende } \\
\text { nt Variable }\end{array}$ & del $^{\text {Mo }}$ & $\mathbf{R}$ & $\mathbf{R}^{2}$ & $\begin{array}{l}\text { Adjust } \\
\text { ed R } \\
\text { Square }\end{array}$ & $\begin{array}{c}\text { Std. } \\
\text { Error of the } \\
\text { Estimate } \\
\end{array}$ \\
\hline$)^{1}$ & Main & I4.0T & CSRP & 1 & $6^{\mathrm{a}} 0.85$ & 0.732 & 0.705 & 0.4338 \\
\hline${ }^{2}$ & Main & CFBA & CSRP & 1 & $\begin{array}{ll} & 0.82 \\
9^{a} & \end{array}$ & 0.687 & 0.658 & 0.4691 \\
\hline $\begin{array}{l}3 \\
\end{array}$ & d Combine & $\begin{array}{c}\mathrm{I} 4.0 \mathrm{~T} \\
\text { and CFBA } \\
\end{array}$ & CSRP & 1 & $\begin{array}{ll} & 0.95 \\
4^{\mathrm{a}} & \\
\end{array}$ & 0.910 & 0.890 & 0.2654 \\
\hline
\end{tabular}

Table-3 Regression Function

\begin{tabular}{|c|c|c|c|c|}
\hline $\begin{array}{l}\text { S } \\
\text { r. } \\
\text { No. }\end{array}$ & Effect & $\begin{array}{l}\text { Predictor } \\
\text { Variable }\end{array}$ & $\begin{array}{l}\text { Depende } \\
\text { nt Variable }\end{array}$ & Regression Function \\
\hline 1 & Main & I4.0T & CSRP & $\mathrm{Z}=(0.074) \mathrm{I} 4.0 \mathrm{~T}-7.006$ \\
\hline 2 & Main & CFBA & CSRP & $\mathrm{Z}=(0.192)^{*} \mathrm{CFBA}+0.098$ \\
\hline 3 & ed Combin & I4.0T and CFBA & CSRP & $\mathrm{Z}=(0.049) * \mathrm{I} 4.0 \mathrm{~T}+(0.118) * \mathrm{CFBA}-5.249$ \\
\hline
\end{tabular}

\section{A) I4.0T Vs (I4.0T + CFBA):}

$\mathrm{R}^{2}$ Value 0.732 with $\mathrm{I} 4.0 \mathrm{~T}$ as an independent variable alone increases to 0.910 when $2^{\text {nd }}$ Independent Variable CFBA added.

Standard Error estimates 0.4338 with one variable drops to 0.2654 (Lower is better) with two variables. With this regression line equation improves.

So better to have both independent variables (I4.0T and CFBA) instead of one independent variable (I4.0T).

\section{B) CFBA Vs (I4.0T + CFBA)}

$\mathrm{R}^{2}$ Value 0.687 with the CFBA as an independent variable alone increases to 0.910 when $2^{\text {nd }}$ Independent Variable I4.0T is added.

Standard Error estimates 0.4691 with one variable drops to 0.2654 (Lower is better) with two variables. With this the regression line equation improves.

So better to have both independent variables (I4.0T and CFBA) instead of one independent variable (CFBA).

\section{C) I4.0T Vs CFBA}

$\mathrm{R}^{2}$ Value 0.687with the CFBA as an independent variable whereas it is 0.732 with the I4.0T as an independent variable Which signifies that I4.0T independent variable is an better predictor than CFBA.

Standard Error estimates of I4.0T Independent variable is 0.4338 whereas it is 0.4691 for CFBA, which signifies that I4.0T is a better predictor than CFBA as its standard error is less than CFBA Standard error estimates.

\section{Conclusion}

1. Both independent variables (I4.0T and CFBA) together are better predictors of CSR 
(Dependent Variable) instead of individual independent variable (I4.0T or CFBA).

2. As $\mathrm{R}^{2}$ value and standard error estimates of I4.0 is better than CFBA, we can say that I4.0

is a better predictor than CFBA.

From the above findings it is a very well proved that Industry 4.0 has a significant impact on CSR practices of the organization. So also, Industry 4.0 practices enhance the ability of the organization in cross functional business activities which are critical for business success.

At the same time cross functional business activities significantly exhibit a positive impact on both Industry 4.0 practices and organizations CSR.

When the individual impact of the Explanatory Variable-1: Industry 4.0 based technologies and Explanatory Variable-2: Cross functional business activities is compared with the combined impact of both these variables on the Response Variable - CSR it is observed that the combined impact is slightly higher than that of individual impact.

Thus, Explanatory Variable-1: Industry 4.0 based technologies and Explanatory Variable-2: Cross functional business activities create a synergisticpositive impact on the organizations CSR performance. And it can be concluded that Industry 4.0 practices play a role of technology enabler in CSR performance of the organizations.

\section{Discussion}

The most popular contemporary themes of business activities of an organization are revolving around the concepts of Sustainable CSR and environment friendly business practices. Industries globally are spending resources on aligning their cross functional business activities along with these themes. CSR is no longer a buzz word in modern day business but one of the key factors in business strategy. Played correctly CSR has a potential of creating a strategic advantage and global acceptability to the business. Industries are striving to achieve competitive advantage on CSR front by using cross functional business activities along with other enablers.

Technology plays a critical role in the current VUCA business world. Businesses are made or ruined because of onslaught of disruptive technologies. Using technology as an enabler for aligning business activities CSR is the endeavour of the modern-day business practices.

Industry 4.0 technology practices is sweeping the entire spectrum of business practices on technology front. Based on integration of cyber, physical, and biological world it has tremendous potential to impact business in all spheres. Industry 4.0 technologies like internet of things, cyber physical systems, artificial intelligence, big data, cloud computing, robotics, cybersecurity, virtual reality and augmented reality, blockchain, additive manufacturing, 5G, and autonomous vehicles have significant impact on all the industries and business practices across the domain.

Industry 4.0 also has a significant impact on the way businesses are conducted from CSR perspective. Along with it also has a significant impact on cross functional business activities. Together, Industry 4.0 and cross functional business activities can synergistically influence CSR of a business in a positive way there by allowing business a competitive advantage.

At the same time industries to take a call on these matters considering the different social challenges and risks associated with these technologies. The research on negative impacts of these technologies like implementation cost, vulnerability, social impacts like skill gap and unemployment is essential element on return on investment. In conclusion, Industry 4.0 promises lot of benefits to the industry business as well as CSR, but companies should adopt a diligent strategy.

\section{References}

A. Bonilla, S., Silva, H., Terra da Silva, M., Franco Gonçalves, R., \&Sacomano, J. (2018). Industry 4.0 and Sustainability Implications: A Scenario-Based Analysis of the Impacts and Challenges. Sustainability, 10(10), 3740. doi: 10.3390/su10103740

B. Campbell, J. (2007). Why would corporations behave in socially responsible ways? an institutional theory of corporate social responsibility. Academy Of Management Review, 32(3), 946-967. doi: 10.5465/amr.2007.25275684 
C. Carroll, A. (1979). A Three-Dimensional Conceptual Model of Corporate Performance. The Academy Of Management Review, 4(4), 497. doi: 10.2307/257850

D. Carroll, A., \& Shabana, K. (2010). The Business Case for Corporate Social Responsibility: A Review of Concepts, Research and Practice. International Journal Of Management Reviews, 12(1), 85-105. doi: 10.1111/j.1468-2370.2009.00275.x

E. Challenges and Solutions for the Digital Transformation and Use of Exponential Technologies; Deloitte: London, UK, 2015; 32p.. (2015).

F. Dahlsrud, A. (2008). How corporate social responsibility is defined: an analysis of 37 definitions. Corporate Social Responsibility And Environmental Management, 15(1), 1-13. doi: 10.1002/csr.132

G. DeNisi, A., Wilson, M., \&Biteman, J. (2014). Research and practice in HRM: A historical perspective. Human Resource Management Review, 24(3), 219-231. doi: 10.1016/j.hrmr.2014.03.004

H. Design Principles for Industrie 4.0 Scenarios. In Proceedings of the 2016 49th Hawaii International Conference on System Sciences (HICSS), Koloa, HI, USA, 5-8 January 2016. (2016).

I. Industry 4.0; Study for the European Parliament's Committee on Industry, Research and Energy (ITRE); European Parliament: Brussels, Belgium, 2016. (2016).

J. KIEL, D., MÜlleR, J., ARNOLD, C., \& VOIGT, K. (2017). SUSTAINABLE INDUSTRIAL VALUE CREATION: BENEFITS AND CHALLENGES OF INDUSTRY 4.0. International Journal Of Innovation Management, 21(08), 1740015. doi: 10.1142/s1363919617400151

K. Koo, J., \& Lee, S. (2015). Linking Corporate Citizenship to Global Citizenship : Who Supports Corporate Social Responsibility?. Korean Journal of Sociology, 49(4), 165. doi: 10.21562/kjs.2015.08.49.4.165

L. Laari, S., Töyli, J., Solakivi, T., \&Ojala, L. (2016). Firm performance and customer-driven green supply chain management. Journal Of Cleaner Production, 112, 1960-1970. doi: 10.1016/j.jclepro.2015.06.150

M. Lu, Y. (2017). Industry 4.0: A survey on technologies, applications and open research issues. Journal Of Industrial Information Integration, 6, 1-10. doi: 10.1016/j.jii.2017.04.005

N. Müller, J., Buliga, O., \& Voigt, K. (2018). Fortune favors the prepared: How SMEs approach business model innovations in Industry 4.0. Technological Forecasting And Social Change, 132, 2-17. doi: 10.1016/j.techfore.2017.12.019

O. Osburg, T. Sustainability in a digital world.

P. Potočan, V., Mulej, M., \&Nedelko, Z. (2020). Society 5.0: balancing of Industry 4.0, economic advancement and social problems. Kybernetes, ahead-of-print(ahead-of-print). doi: 10.1108/k-12-20190858

Q. Recommendations for Implementing the Strategic Initiative Industrie 4.0; National Academy of Science and Engineering: Munich, Germany, 2013. (2013).

R. Scavarda, A., Daú, G., Scavarda, L., \&GoyannesGusmãoCaiado, R. (2019). An Analysis of the Corporate Social Responsibility and the Industry 4.0 with Focus on the Youth Generation: A Sustainable Human Resource Management Framework. Sustainability, 11(18), 5130. doi: 10.3390/su11185130

S. Stock, T., Obenaus, M., Kunz, S., \& Kohl, H. (2018). Industry 4.0 as enabler for a sustainable development: A qualitative assessment of its ecological and social potential. Process Safety And Environmental Protection, 118, 254-267. doi: 10.1016/j.psep.2018.06.026

T. Towards a green economy: Pathways to sustainable development and poverty eradication. (2011).

U. Wan, J. (2011). Advances in Cyber-Physical Systems Research. KSII Transactions On Internet And Information Systems, 5(11). doi: 10.3837/tiis.2011.11.001

V. Wang, S., Wan, J., Li, D., \& Zhang, C. (2016). Implementing Smart Factory of Industrie 4.0: An Outlook. International Journal Of Distributed Sensor Networks, 12(1), 3159805. doi: $10.1155 / 2016 / 3159805$ 